\title{
Sistem Informasi Peminjaman Barang Berbasis Web dengan Metode Waterfall
}

\author{
MUHAMMAD NUGRAHA, JAMALUDIN YASKURNIAAM
}

Program Studi Teknologi RPL, Politeknik Enjinering Indorama

Email: nugraha@pei.ac.id

Received 25 Maret 2020| Revised 25 April 2020 | Accepted 28 Mei 2020

\begin{abstract}
ABSTRAK
Proses peminjaman barang untuk keperluan praktikum merupakan aktifitas yang rutin dilakukan. Pada umumnya peminjaman barang dilakukan oleh mahasiswa atau dosen kepada staf laboratorium dengan mengisi form peminjaman secara tertulis. Namun dalam proses peminjaman tersebut ada kalanya staf laboratorium kewalahan ketika proses peminjaman barang banyak sekali karena staf laboratorium harus mengecek keberadaan barang satu persatu secara manual. Oleh karena permasalahan tersebut maka pada penelitian ini akan didesain dan dibangun sistem informasi peminjaman barang berbasis web yang berfungsi untuk mempermudah staf laboratorium dalam pengelolaan data barang. Dengan sistem informasi peminjaman barang proses pengajuan peminjaman, persetujuan peminjaman, monitoring barang, dan pencarian status barang bisa dengan mudah dan cepat dilakukan. Metode pembangunan sistem yang digunakan pada penelitian ini menggunakan metode Waterfall, dan untuk desain sistem menggunakan UML (Unified Modelling Languange). Hasil akhir dari penelitian ini berupa sistem informasi peminjaman barang berbasis web dengan menggunakan framework Codeigniter 4 yang dapat mempermudah proses pengelolaan peminjaman barang.
\end{abstract}

Kata kunci: sistem, informasi, peminjaman, Codeigniter, web

\begin{abstract}
The borrowing process goods for practicum is a routine activity. Generally, the lending of goods is carried out by students to laboratory staff by filling out the loan form manually. However, in the lending process, sometimes laboratory staff is overwhelmed when the process of borrowing a lot because the laboratory staff has to check the items manually. Base on these problems, this research will develop a web-based information system for lending goods to facilitate laboratory staff in managing data of goods. With this information system for borrowing goods, the process of applying for loans, loan approval, monitoring of goods, and searching for the status of goods can be done easily and quickly. The method of development system using Waterfall, and system design using UML. The final result of this research is a web-based information system for lending goods using the Codeigniter 4 framework, which can simplify managing lending of goods.
\end{abstract}

Keywords: system, information, loan, Codeigniter, web 


\section{PENDAHULUAN}

Pelayanan terhadap mahasiswa, dosen, dan staf pada sebuah kampus merupakan aspek yang sangat penting, karena dengan pelayanan yang prima maka seluruh civitas akademika akan merasa puas dan akan berdampak baik pada kualitas dari institusi itu sendiri. Ada banyak jenis pelayanan yang ada di kampus seperti pelayanan pendaftaran mahasiswa baru, pelayanan administrasi, pelayanan akademik, pelayanan konsultasi dosen wali, pelayanan karir, dan yang tidak kalah penting yaitu pelayanan peminjaman fasilitas kampus. Banyak fasilitas kampus yang bisa dimanfaatkan oleh seluruh civitas akademika seperti peminjaman barang untuk praktek atau untuk penelitian. Pada umumnya peminjaman barang dilakukan oleh mahasiswa atau dosen kepada staf laboratorium dengan mengisi form peminjaman secara tertulis, jika alat yang akan dipinjam ada dan dalam kondisi baik maka alat tersebut akan dipinjamkan dan harus dikembalikan sesuai dengan lama peminjaman yang telah diisi di form peminjaman. Namun dalam proses peminjaman tersebut ada kalanya staf lab kewalahan ketika proses permintaan peminjaman barang banyak sekali karena staf laboratorium harus memeriksa keberadaan barang satu persatu secara manual, apakah barang yang akan dipinjam masih digunakan oleh pengguna lain atau ada di tempat penyimpanan. Oleh karena permasalahan tersebut maka pada penelitian ini akan didesain dan dibangun sistem informasi peminjaman barang berbasis web yang berfungsi untuk mempermudah staf laboratorium dalam pengelolaan data alat atau barang yang dimiliki kampus. Dengan sistem informasi peminjaman alat ini proses pengajuan peminjaman, persetujuan peminjaman, monitoring barang, pengecekan stok barang, dan pencarian status barang bisa dengan mudah dan cepat dilakukan oleh pengguna.

Perancangan dan implemntasi sistem informasi peminjaman pernah dilakukan oleh beberapa penelitian terdahulu dengan studi kasus yang berbeda-beda, diantaranya: "Sistem Informasi Peminjaman Ruang Dan Barang Di Universitas Muria Kudus Berbasis Web Menggunakan Fitur Sms Notification" pada penelitian tersebut peneliti membuat sistem informasi peminjaman ruang dan barang berbasis web dan feature sms gateway. Sistem yang dibangun dalam penelitian tersebut tidak menggunakan framework dengan model MVC dan UI/UX yang digunakan masih perlu lagi dikembangkan agar lebih nyaman dan mudah digunakan oleh user (Khasbi et al., 2016). Selain itu ada juga penelitian "Rancang Bangunsistem Informasi Peminjaman perangkat Demo Video Conference Berbasis web dengan Metode Waterfall' yang diimplementasikan di PT. Aliansi Sakti sebagai sistem informasi pendataan perangkat demo unit. Sama halnya seperi pada peneliti sebelumnya, pada penelitian ini sistem yang dibangun belum menggunakan framework berbasis MVC sehingga sistem yang dibangun lebih rapih dan tertata, dan dari segi keamananpun lebih bagus (Christian, Ade \& Ariani, 2018). Ada juga rancang bangun sistem informasi peminjaman buku yang diimplementasikan di SMP Negeri 1 Madiun, pada penelitian tersebut sistem dibuat dengan menggunakan PHP dengan sangat sederhana baik dari segi tampilan ataupun feature sistem (Putera \& Ibrahim, 2018).

Berdasarkan beberapa poin permasalahan dan hasil kajian terdahulu pada pembahasan di atas maka dapat dirumuskan sebuah solusi untuk mendesain dan membangun sebuah sistem informasi peminjaman barang berbasis web dengan menggunakan framework Codeigniter 4 yang berjalan di berbagai device seperti PC dan atau mobile. Pada penelitian ini metode yang akan digunakan adalah Waterfall dan metode desain sistem menggunakan UML. Hasil akhir dari penelitian ini adalah terbentuknya sistem informasi peminjaman barang berbasis web yang dapat membantu staf laboratorium dalam proses monitoring barang yang dimilki kampus baik yang sedang dipinjam ataupun tidak. 


\section{METODE PENELITIAN}

Metode penelitian yang digunakan pada penelitian ini yaitu metode kualitatif yang mana pada penelitian ini proses pengumpulan data dan informasi dilakukan dengan cara observasi dan studi literatur. Adapun metode pengembangan sistem yang dilakukan pada penelitian ini menggunakan metode Waterfall (Sarosa, 2017), yaitu tahapan dimulai dari analisis masalah dan kebutuhan, desain sistem, implementasi, testing, dan terakhir maintenance.

\subsection{Analisis Kebutuhan}

Pada tahapan ini peneliti mengidentifikasi masalah dan mengumpulkan data yang dibutuhkan untuk dianalisis, sehingga hasil dari proses analisis ini bisa di gunakan untuk proses desain sistem sesuai dengan kebutuhan.

\subsection{Desain Sistem}

Setelah selesai melakukan analisis kebutuhan maka langkah selanjutnya adalah melakukan desain sistem yang akan di implementasikan. Pada tahapan ini peneliti akan mendesain sistem mulai dari desain basis data yang direpresentasikan dengan ERD, desain sistem dengan menggunakan model UML, dan terakhir desain user interface dengan menggunakan mockup aplikasi.

\subsection{Implementasi}

Tahapan ini merupakan tahapan pengkodean atau pembuatan aplikasi. Proses implementasi aplikasi harus mengacu berdasarkan hasil desain sistem yang telah dibuat sebelumnya. Pada tahapan ini yang di lakukan adalah mengimplementasikan ERD menjadi tabel fisik di database, membuat tampilan berdasarkan mockup yang telah didesain, dan pengkodean berdasarkan perancangan dari UML pada tahap desain sistem.

\subsection{Testing}

Testing yang dilakukan bertujuan untuk menetukan apakah sistem yang di bangun sesuai dengan kebutuhan pengguna atau tidak. Tahapan ini juga bertujuan untuk meminimalisir kesalahan dan ketidaksesuaian input output pada sistem.

\subsection{Maintenance}

Maintenance dilakukan setelah sistem jadi dan lulus proses testing. Tahapan ini cukup penting mengingat perkembangan tehnologi dan kebutuhan user yang akan selalu uptodate setiap saat. Maintenance dilakukan ketika ada bugs atau ada penambahan feature yang dibutuhkan di kemudian hari.

\section{HASIL DAN PEMBAHASAN}

Berdasarkan hasil analisis kebutuhan yang telah dilakukan maka dapat didesain dan di implementasikan sebuah desain sistem informasi peminjaman barang berbasis web dengan hasil seperti berikut:

\subsection{Desain Basis Data}

Desain basis data merupakan acuan dalam pengelolaan data yang akan diproses pada sistem yang akan di bangun (Prasetyo, 2015). Pada tahap desain basis data ini terdapat beberapa tabel yang memiliki atribut dan saling berelasi antara satu sama lainnya. Adapun bentuk relasi tersebut dapat digambarkan dengan sebuah ERD pada Gambar 1 berikut ini. 

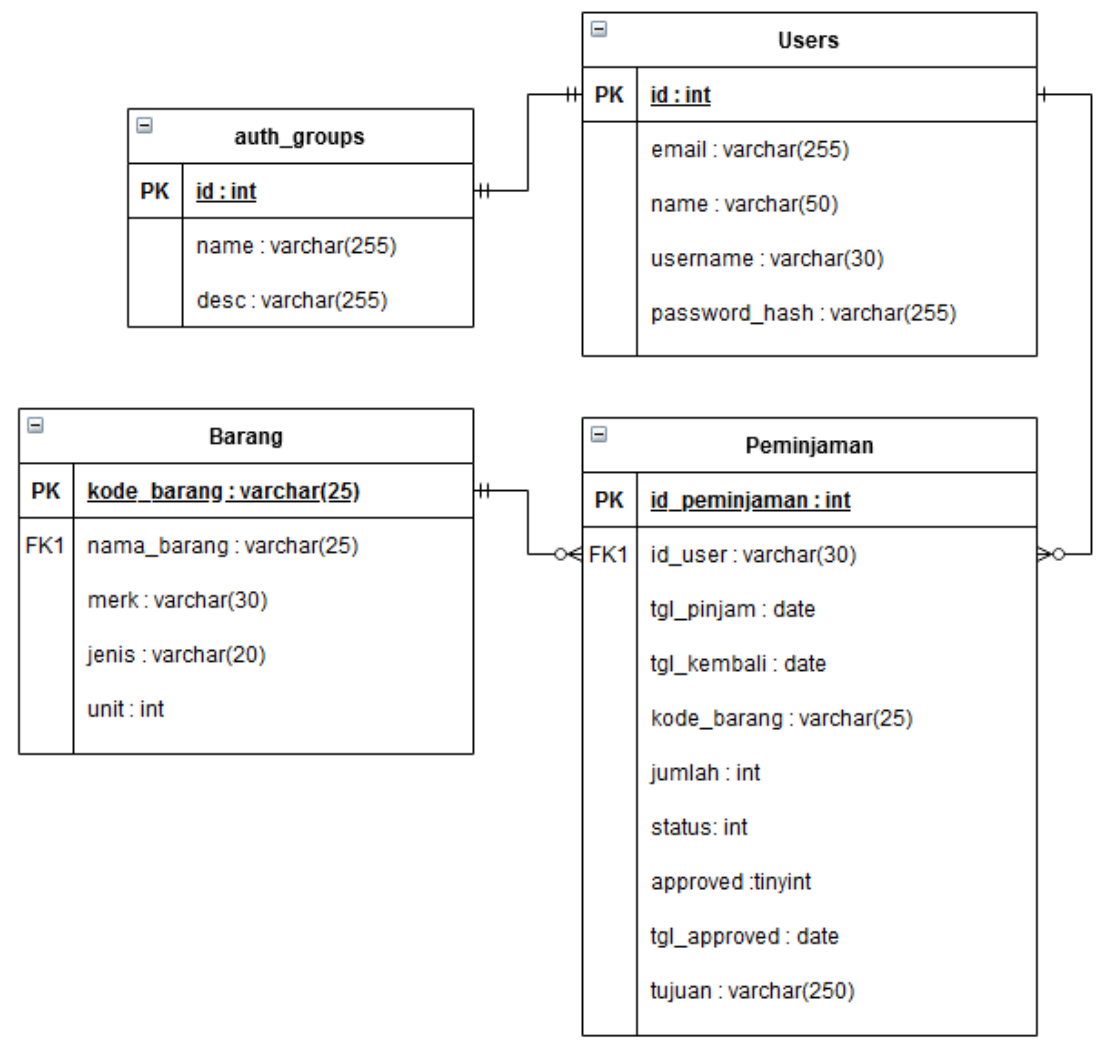

Gambar 1. ERD Sistem Informasi peminjaman Barang

\subsection{Use Case Diagram}

Use Case Diagram yang merupakan gambaran umum tentang fungsionalitas sistem atau proses bisnis dari persprektif pengguna(Munawar, 2018). Titik awal dalam membuat use case diagram dilihat dari bagaimana user menggunakan sistem. Adapun use case diagram dari sistem yang akan dibangun seperti pada Gambar 2 berikut ini.

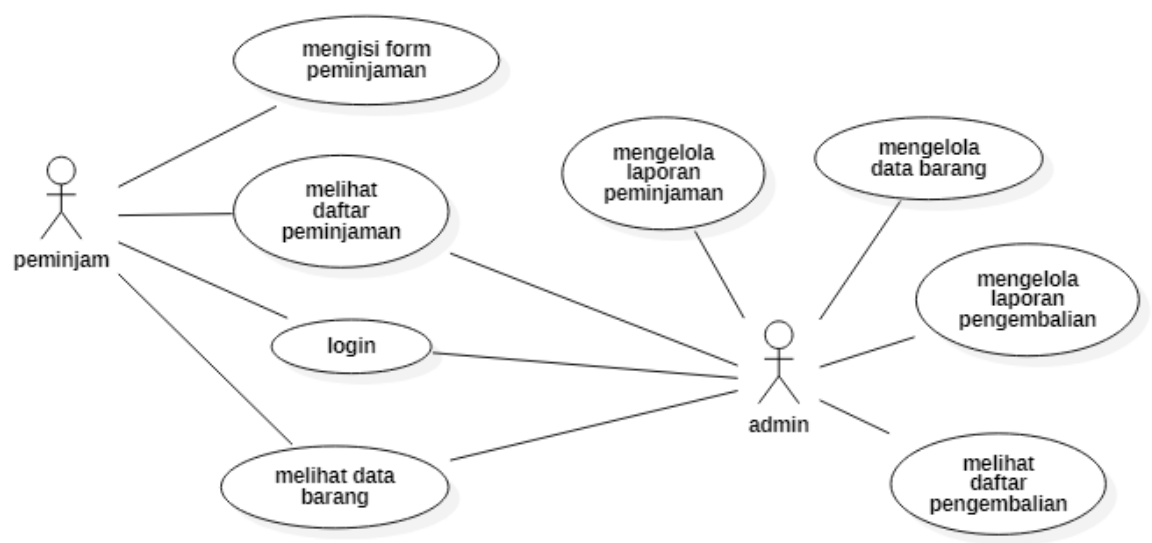

Gambar 2. Use Case Diagram Sistem Informasi Peminjaman Barang 


\subsection{Activity Diagram}

Activity diagram menunjukan alur program yang terjadi antara user dan sistem yang berjalan (Sugiarti, 2013). Setiap proses pada sistem akan digambarkan dengan diagram activity, di antaranya:

\subsubsection{Activity Melihat Data}

Activity melihat data ini prosesnya semua sama baik pada data user, barang, meminjam, dan pengembalian. namun untuk mempersingkat pembahasan, pada bagian ini proses activity yang akan di bahas adalah activity melihat barang. Aktifitas melihat data barang dilakukan setelah user berhasil login dan memilih menu master data barang pada dashboard. Data barang yang berada di database akan dipanggil dan ditampilkan di halaman data barang seperti activity pada Gambar 3 berikut ini.

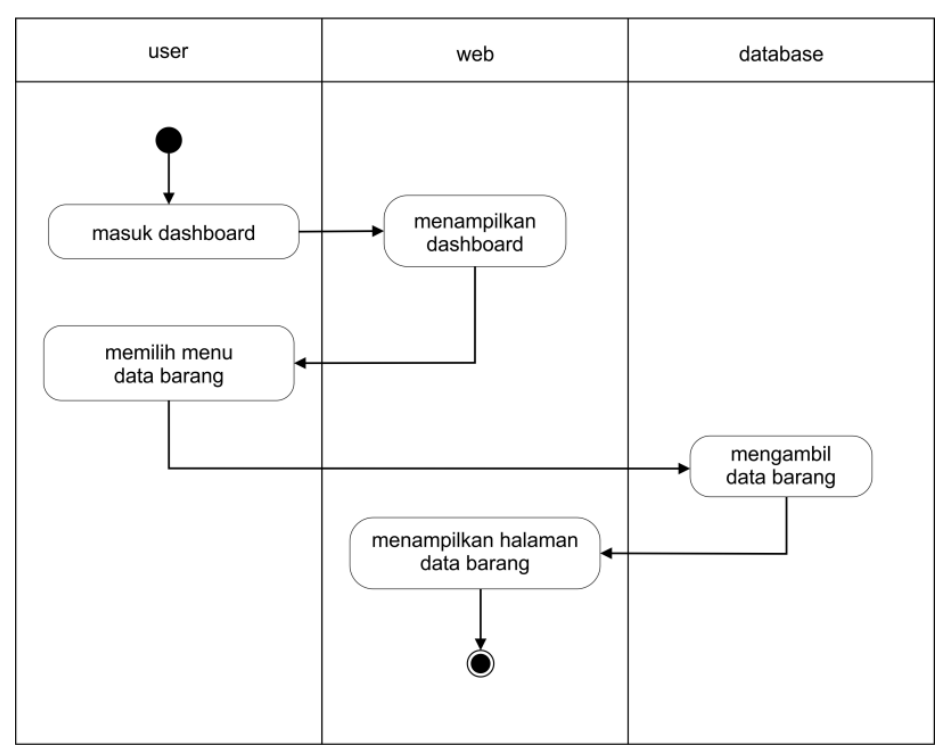

Gambar 3. Activity Diagram Melihat Data Barang

\subsubsection{Activity Input Data}

Activity input data ini prosesnya semua sama baik pada data user, barang, meminjam, dan pengembalian. namun untuk mempersingkat pembahasan, pada bagian ini proses activity yang akan dibahas adalah activity input data peminjaman. Aktifitas melihat data peminjaman dilakukan setelah user berhasil login dan memilih menu peminjaman pada dashboard. Data peminjaman barang yang dimasukkan pada halaman peminjaman akan dikirim ke dalam tabel peminjaman seperti pada Gambar 4 berikut ini. 


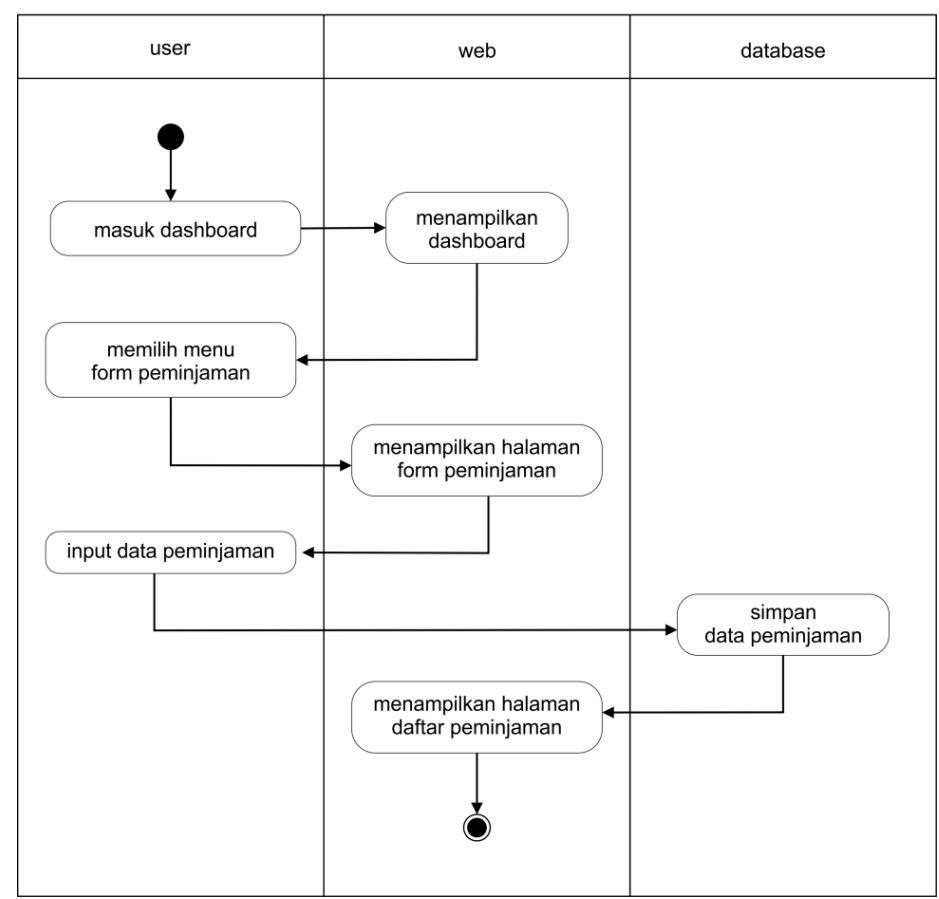

Gambar 4. Activity Diagram Input Data Peminjaman

\subsection{Class Diagram}

Class diagram digunakan untuk memvisualisasi dan mengkonstruksi sebuah sistem object oriented. Class diagram dalam sebuah UML merupakan tipe diagram yang mendeskripsikan struktur sebuah sistem dengan menampilkan class, atribut, method, dan relasi antar object (Paradigm, 2021). pada Gambar 5 di bawah ini ditunjukan class diagram yang menampilkan 4 class yang saling berelasi. Setiap class memiliki atribut dan method yang akan diimplementasikan pada sistem.

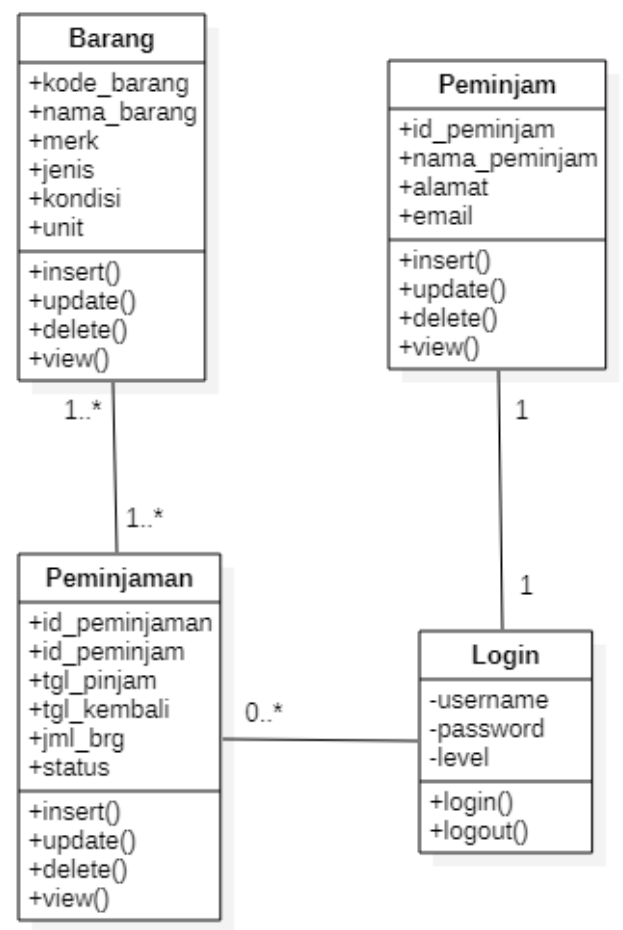

Gambar 5. Class Diagram Sistem Informasi Peminjaman Barang 


\subsection{HASIL IMPLEMENTASI}

Pada bagian ini merupakan pembahasan hasil dari analisis dan desain sistem yang diimplementasikan menjadi sebuah aplikasi Sistem Informasi Peminjaman Barang Berbasis Web dengan menggunakan database MySQL dan framework Codeigniter 4. Adapun hasil dari implemntasi sistem ini meliputi:

\subsubsection{Login}

Feature login dibuat dengan menggunakan plugin myth-auth yang merupakan salah satu plugin yang berfungsi untuk mengatur proses autentikasi pengguna berdasarkan jenis user dan jenis permisinya (Ezell, 2021). Login akan otomatis dijalankan ketika membuka sistem, jadi user akan diminta untuk memasukan username dan password untuk bisa masuk ke halaman dashboard seperti pada Gambar 6.

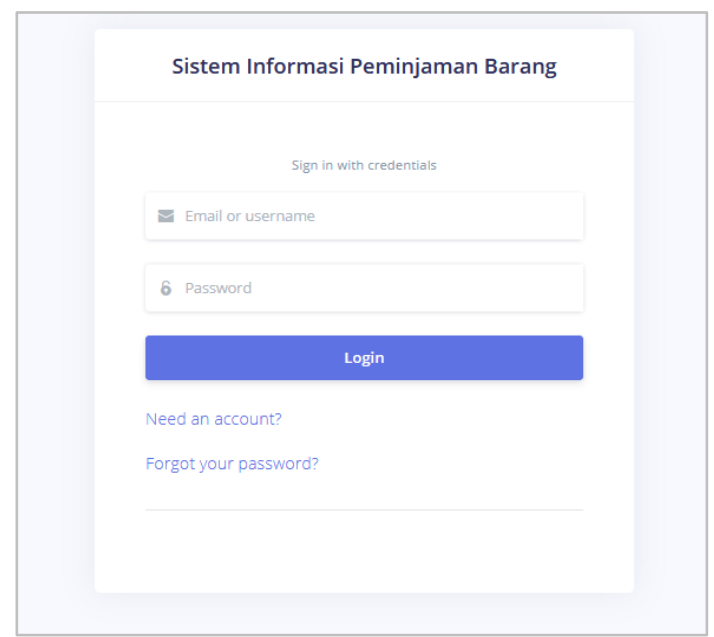

Gambar 6. Halaman Login

\subsubsection{Dashboard}

Halaman dasboard admin akan ditampilkan setelah admin berhasil login. Dashboard akan menampilkan total barang, total semua transaksi peminjaman, total semua transaksi pengembalian dan jumlah akun yang terdaftar seperti pada Gambar 7.

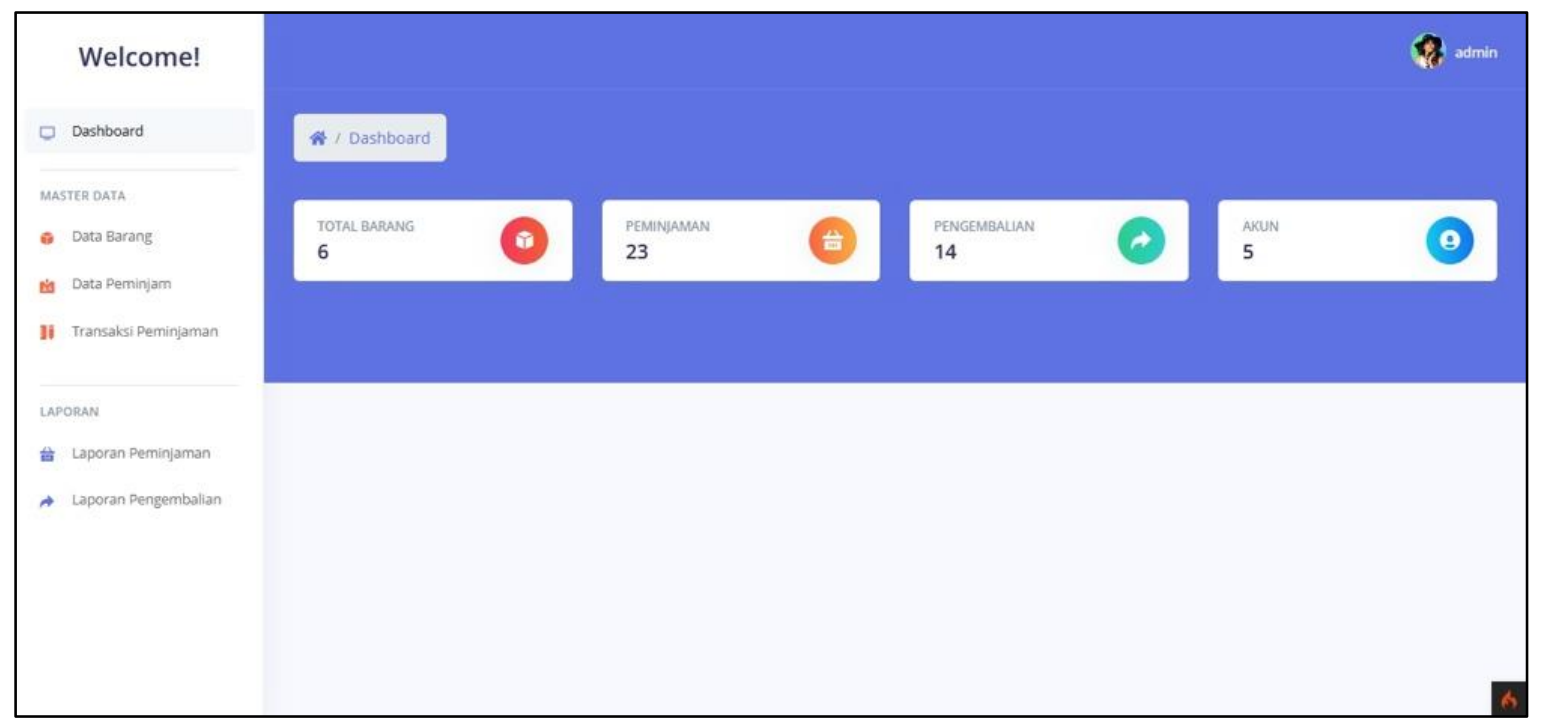

Gambar 7. Halaman Dashboard 


\subsubsection{Halaman Kelola Data Barang}

Halaman barang berfugnsi untuk mengelola data barang, baik itu untuk melihat, memasukan, merubah, menghapus, atau mencari data barang. Adapun tampilan halaman data barang seperti pada Gambar 8 berikut ini.

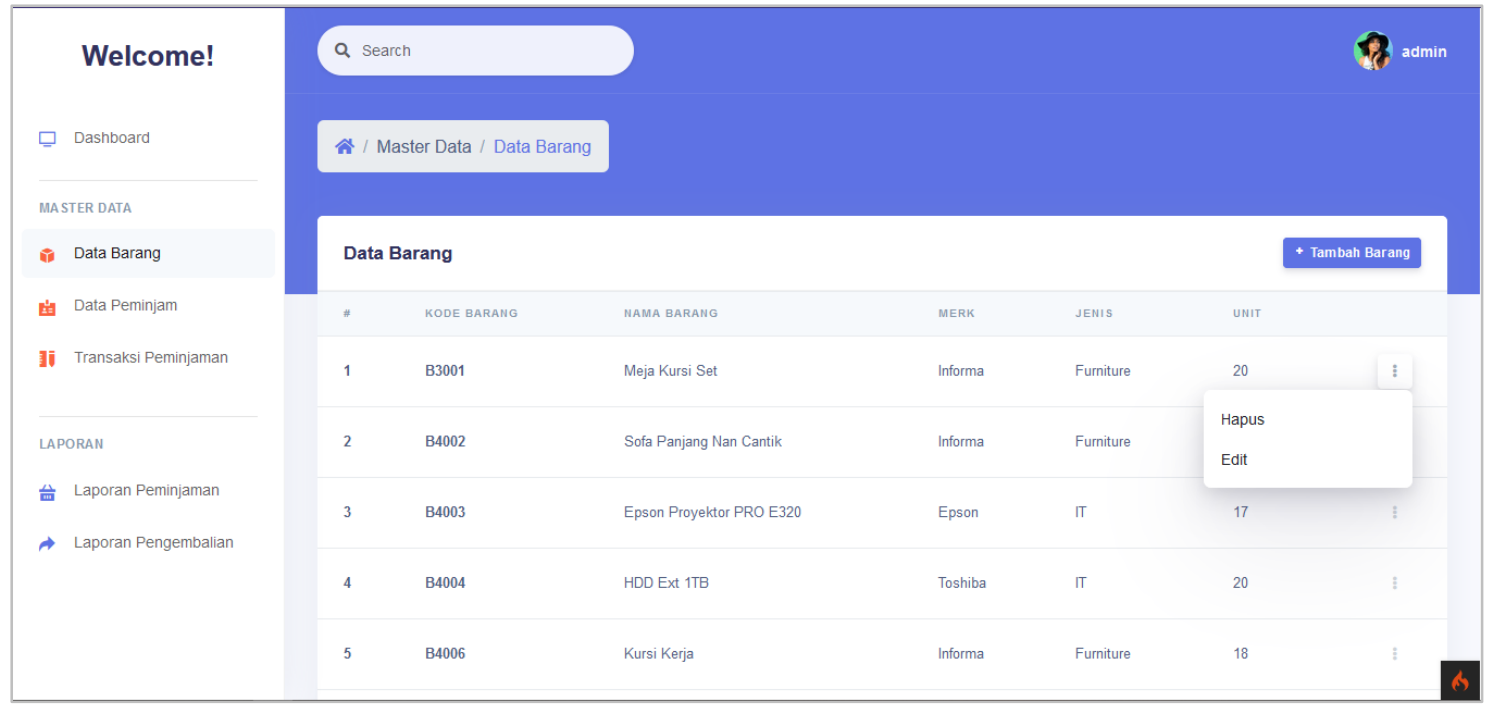

Gambar 8. Halaman Data Barang

\subsubsection{Halaman Input Data Barang}

Halaman input data barang seperti pada Gambar 9 menampilkan form pengisian data barang dengan validasi pada input kode barang dan nama barang yang wajib diisi. Jika input jumlah unit tidak diisi, maka sistem akan memasukan default nilai 0 . Ketika user berhasil memasukan data barang pada halaman input data barang, maka data tersebut akan masuk ke dalam tabel barang dan data akan ditampilkan di halaman kelola data barang. Adapun untuk proses edit data tampilanya sama dengan form input data.

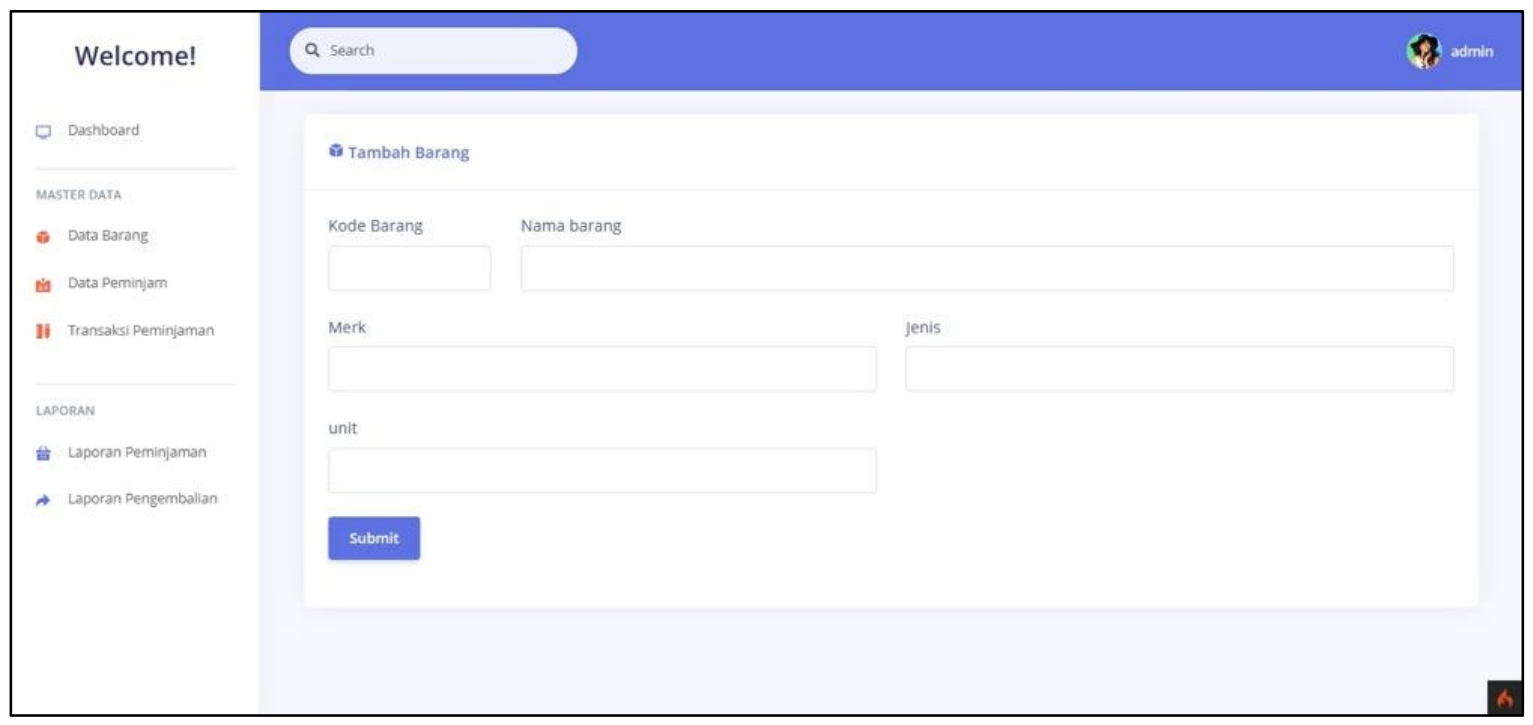

Gambar 9. Form Input Data Barang

\subsubsection{Halaman Transaksi Peminjaman}

Halaman peminjaman berfungsi untuk mengelola transaksi peminjaman apakah peminjaman yang diajukan itu akan diterima atau ditolak seperti pada Gambar 10. Status 
diterima atau ditolak dapat dilihat pada kolom status peminjaman barang. Admin atau operator dapat menetukan status dengan cara memilih pilihan pada bagian konfirmasi.

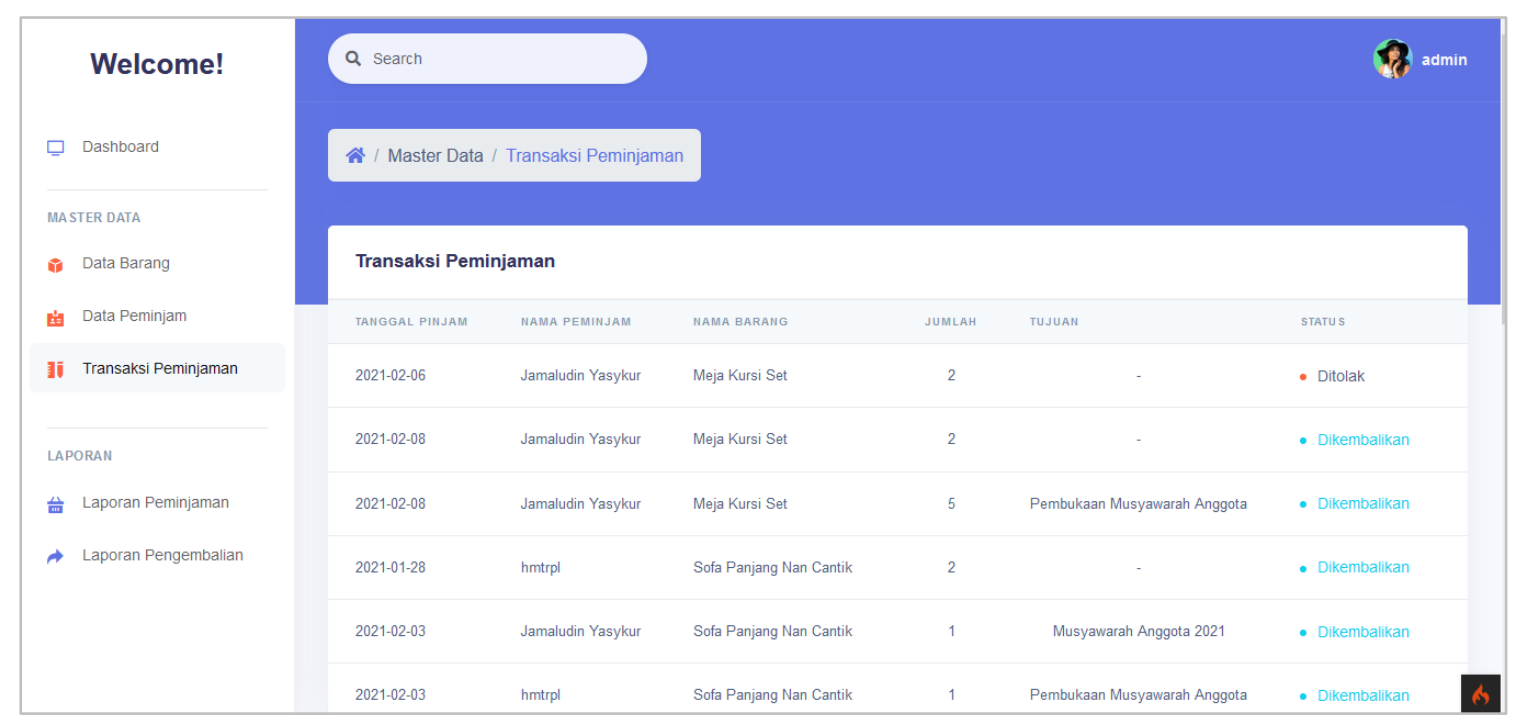

Gambar 10. Halaman Transaksi Peminjaman

\subsection{HASIL PENGUJIAN}

Pengujian dilakukan dengan menggunakan User Acceptance Testing (UAT) yang melibatkan end user untuk pengujiannya. Pada pengujian ini melibatkan 50 user yang terdiri dari komponen dosen, mahasiswa, dan staf yang sebelum proses pengisian kuesionernya seluruh user di berikan tutorial penggunaan sistem. Intrument pengujian yang digunakan berupa kuesioner dengan skala pengukuran menggunakan skala likert. Point skala penilaian dibagi mejadi 5 jawaban, yaitu sangat tidak setuju, tidak setuju, ragu-ragu, setuju, dan sangat setuju. UAT ini dilakukan untuk mengetahui sejauh mana tingkat penerimaan sistem yang telah di bangun apakah hasil yang dihasilkan sesuai dengan yang diharapkan atau tidak. Adapun hasil penilaiannya seperti pada Tabel 1 dengan kategori variable penilaian di bagi jadi 3 bagian.

Tabel 1. Hasil Pengujian Sistem

\begin{tabular}{|l|c|c|c|c|c|}
\hline \multirow{2}{*}{$\begin{array}{c}\text { Variabel } \\
\text { Penilaian }\end{array}$} & \multicolumn{5}{|c|}{ Frequensi Jawaban } \\
\cline { 2 - 6 } & $\begin{array}{c}\text { Sangat } \\
\text { Setuju }\end{array}$ & Setuju & Ragu-ragu & Tidak Setuju & $\begin{array}{c}\text { Sangat Tidak } \\
\text { Setuju }\end{array}$ \\
\hline Desain & 19 & 31 & 0 & 0 & 0 \\
\hline Kemudahan & 11 & 39 & 0 & 0 & 0 \\
\hline Efisiensi & 21 & 29 & 0 & 0 & 0 \\
\hline \multicolumn{1}{|c|}{ Total } & $\mathbf{5 1}$ & $\mathbf{9 9}$ & $\mathbf{0}$ & $\mathbf{0}$ & $\mathbf{0}$ \\
\hline
\end{tabular}

Sehingga dari data tabel di atas didapat perhitungan presentase penerimaan dengan menggunakan Persamaan (1).

$$
P=\frac{f}{n} \times 100 \%
$$

$\begin{array}{lll}\text { Frequensi Jawaban } & : & 51 \times 5=255 \\ & \frac{99 \times 4=396}{651}+ \\ \text { Nilai maksimum penilaian } & : & 50 \times 5 \times 3=750 \\ \text { Presentase penerimaan } & : & \frac{651}{750} \times 100 \%=86,8 \%\end{array}$




\section{KESIMPULAN}

Berdasarkan hasil penelitian yang telah dilakukan maka diperoleh kesimpulan bahwa sistem informasi peminjaman barang berbasis web dengan framework Codeigniter 4 dapat berjalan sesuai kebutuhan dan dapat memberikan kemudahan baik untuk pengelola staf peminjaman barang dan user yang meminjam barang. Sebanyak $86.8 \%$ user menerima terhadap sistem ini dan menyatakan bahwa sistem yang telah di bangun dapat membantu dan mempermudah proses peminjaman barang. Maka dapat disimpulkan dengan adanya sistem ini user menjadi lebih mudah dan cepat dalam pengajuan karena dapat diakses dengan menggunakan web browser dari mana saja, sehingga produktifikas menjadi lebih efektif dan efisien.

\section{DAFTAR RUJUKAN}

Christian, Ade, \& Ariani, F. (2018). Rancang Bangun Sistem Informasi Peminjman Perangkat Demo Video Confrence Berbasis Web Dengan Metode Waterfall. PILAR Nusa Mandiri, 14(1), 109-111.

Ezell, L. (2021). Myth Auth. https://github.com/lonnieezell/myth-auth

Khasbi, I., Nugraha, F., \& Muzid, S. (2016). Sistem Informasi Peminjaman Ruang Dan Barang Di Universitas Muria Kudus Berbasis Web Menggunakan Fitur Sms Notification. Simetris: Jurnal Teknik Mesin, Elektro Dan IImu Komputer, Л2), 513. https://doi.org/10.24176/simet.v7i2.762

Munawar. (2018). Analisis Perancangan Sistem Berorientasi Objek Dengan UML. Informatika.

Paradigm, V. (2021). UML Class Diagram. https://www.visual-paradigm.com/guide/umlunified-modeling-language

Prasetyo, H. N. (2015). Perancangan Dan Implementasi Basis Data (Jilid 1). Deepublish.

Putera, A. R., \& Ibrahim, M. (2018). Rancang Bangun Sistem Informasi Peminjaman dan Pengembalian Buku Perpustakaan SMP Negeri 1 Madiun. DoubleClick: Journal of $\begin{array}{lllll}\text { Computer and Information Technology, } & \text { 1(2), }\end{array}$ https://doi.org/10.25273/doubleclick.v1i2.2025

Rasimin. (2018). Metode Penelitian Pendekatan Praktis Kualitatif. Mitra Cendikia.

Sarosa, S. (2017). Metodologi Pengembangan Sistem Informasi. INDEKS.

Sugiarti, Y. (2013). Analisis Dan Perancangan UML (Unified Modeling Language). Graha Ilmu. 